\title{
CCNE1 wt Allele
}

National Cancer Institute

\section{Source}

National Cancer Institute. CCNE1 wt Allele. NCI Thesaurus. Code C49525.

Human CCNE1 wild-type allele is located within $19 q 12$ and is approximately $12 \mathrm{~kb}$ in length. This allele, which encodes G1/S-specific cyclin-E1 protein, is involved in the regulation of the G1/S transition of the cell cycle. Variant allelic overexpression has been observed in many tumors, which results in chromosome instability, and thus may contribute to tumorigenesis. 